\title{
ANALISIS KESALAHAN SISWA DALAM MENYELESAIKAN PERMASALAHAN SISTEM PERSAMAAN LINEAR DUA VARIABEL
}

\author{
Hilza Karyawati Indriani ${ }^{1 *}$, Dedy Juliandri Panjaitan ${ }^{2}$ \\ Program Studi Pendidikan Matematika, Universitas Muslim Nusantara Al-Washliyah ${ }^{1,2}$ \\ Email : hilza.k.indiani@gmail.com*
}

\begin{abstract}
Abstrak
Tujuan penelitian supaya dapat mengetahui kesalahan dan faktor yang menyebabkan kesalahan siswa saat mengerjakan SPLDV. Penelitian ini mengggunakan pendekatan kualitatif dengan jenis penelitian deskriptif kualitatif. Subjek penelitian yakni seluruh siswa kelas VIII A MTs Persiapan Negeri Desa Pulau Tagor, dan memilih 3 siswa sebagai subjek wawancara. Instrumen penelitian ini terdiri dari tes tertulis dan wawancara tidak terstruktur. Hasil analisis ditemukan. 4 siswa mendapatkan predikat B melakukan kesalahan sedikit dengan rentang nilai 84-92 memenuhi KKM, ditemukan 8 siswa mendapatkan predikat $C$ dan D melakukan kesalahan banyak dengan rentang nilai 75-83 dan < 75 nilai dibawah KKM. Kesimpulan penelitian ditemukan kesalahan konsep sebanyak 95,65\% Kesalahan prinsip dan operasi sebanyak $86,95 \%$. Faktor yang menyebabkan kesalahan yakni: tidak paham konsep, hanya fokus pada contoh yang diberikan guru. tidak menguasai operasi aljabar. tidak hati-hati menjawab soal.
\end{abstract}

Kata Kunci : SPLDV, Kesalahan siswa

\section{Abstract}

The purpose of this research is to find out the errors and factors that cause student errors during working on the SPLDV. This research uses a qualitative with a qualitative descriptive type of research. The research subjects were all students of class VIII A MTs Persiapan Negeri of Tagor Island Village, and selected 3 students as interview subjects. The research instrument consisted of a written test and an unstructured interview. The results of the analysis were found, 4 students getting predicate $B$ made a few mistakes with a value range of 84-92 fulfilling the KKM, it was found that 8 students getting predicate $C$ and $D$ made a lot of mistakes with a value range of 75-83 and $<75$ scores below the KKM. The conclusion of the study was that there were $95.65 \%$ conceptual errors and $86.95 \%$ errors in principle and operation. Factors that cause errors are: not understanding the concept, only focusing on the examples given by the teacher. do not master algebraic operations. careless in answering questions.

Key Words : Two Variable System of Linear Equations, Understudy Blunder

\section{PENDAHULUAN}

Matematika adalah mata pelajaran yang harus dipelajari di setiap tingkat pengajaran, karena matematika merupakan landasan utama dari ilmu pengetahuan. Menguasai hal mengenai matematika akan memudahkan supaya dapat paham tentang pelajaran yang lain seperti kimia, biologi, fisika, bahkan ilmu sosial karena matematika merupakan dasar dari pengetahuan [1]. Matematika mempunyai keterkaitan serta termasuk pendorong dari berbagai bidang ilmu dan berbagai dari aspek kehidupan manusia [2]. Berdasarkan pernyataan tersebut sudah membuktikan betapa diperlukannya pembelajaran tersebut bagi para pelajar. beberapa siswa menganggap pelajaran menghitung yang paling sulit dibandingkan dengan mata pelajaran lainnya serta dianggap sebagai mata pelajaran yang sangat ditakuti bagi siswa. Kesulitan siswa paham tentang materi membuat murid melakukan kekeliruan terutama pada mata pelajaran SPLDV.

Sesudah dilaksanakannya wawancara terhadap guru matematika di MTs Persiapan Negeri Desa Pulau Tagor di kelas VIII A, mengatakan bahwa terdapat 
beberapa kesalahan yang sering terjadi dalam mengerjakan masalah sistem persamaan linear dua variabel misalnya: siswa sering melakukan kesalahan saat mengerjakan operasi bilangan, kesalahan konsep dan prinsip dalam mengerjakan masalah sistem persamaan linear 2 variabel, dan kesalahan dalam membuat model matematika. Hal ini disebabkan kurangnya penguasaan materi matematika khususnya sistem persamaan linear dua variabel, kurangnya ketelitian para siswa dalam menjawab tugas soal serta kurang paham konsep dan juga prinsip dari pembahasan mengenai sistem persamaan linear 2 variabel.

Analisis kesalahan adalah penyelidikan terhadap suatu penyimpangan dalam mengerjakan masalah, dengan demikian mengetahui peristiwa penyimpangan itu dapat terjadi. Hasil penyelidikan memang menemukan bahwa siswa membuat kesalahan yang diperhitungkan dalam hampir semua pertanyaan dengan tingkat kesalahan, yakni: disoal 1 sebanyak $62 \%$. disoal 3 sebanyak $80 \%$. disoal nomor 4 sebanyak $25 \%$, disoal 5 sebanyak $50 \%$., disoal nomor 6a serta 6 c sebanyak $83 \%$., disoal nomor $6 \mathrm{~b}, 6 \mathrm{~d}$, 6e sebanyak $100 \%$, dan disoal cerita disoal 8 serta 9 sebanyak $86 \%$ serta $7 \%$ [3].

Riset ini bertujujuan untuk mengetahui kesalahan yang dilaksanakan siswa dalam mengerjakan masalah SPLDV dan mengetahui faktor yang menyebabkan terjadinya kesalahan yang dibuat oleh muridVIII A MTs Persiapan Negeri Desa Pulau Tagor Kec. Serba Jadi dalam penelitian ini analisis kekeliruan. Tujuan di atas sesuai dengan yang sudah dipaparkan oleh yakni: a) Indikator dari kesalahan konsep, yaitu Kekeliruan konsep merupakan kekeliruan yang dilaksanakan oleh siswa dalam melakukan konsepkonsep yang bekenaan dengan materi soal, di antaranya: 1) Keliru dalam pengertian makna soal; 2) Keliru mengartikansoal kemodel matematika; 3) Keliru tentang konsep variabel yang akan dipakai dalam membuat model dari matematika; dan 4) Keliru konsep tentang teknik substitusi maupun eliminasi. b) Indikator mengenai kesalahan prinsip, yaitu kekeliruan prinsip adalah kekeliruan pada saat memakai syarat-syarat ataupun rumus-rumus dari matematika serta keliru dalam memakai pedomanyang berkenaan dengan pembelajaran, contohnya halnya keliru dalam mengambil simpulan supaya dapat mencari jawaban terakhir dari soal. c) Indikator tentang kekeliruan operasi yaiyu kekeliruan operasi ialah kekeliruan dalam mengerjakan mengenai perhitungan ataupun operasi. yang menyebabkannya yakni murid tidak bisa memakai syarat dari perhitungan yang sesuai)[4].

\section{METODE}

Penelitian ini menggunakan deskriptif kualitatif, dengan memakai pendekatan kualitatif. Penelitian deskriptif sendiri dalam pelaksanaannya mempunyai tahaptahap yakni: dimulai dengan adanya permakeliruan, kemudian menentukan jenis informasi yang akan diperlukan, menentukan prosedur yang dipakai dalam menghimpun infromasi melalui observasi (pengamatan), pengolahan mengenai informasi atau informasi diakhiri dengan menarik simpulan [5].

Lokasi penelitian akan dilaksanakan di MTs Persiapan Negeri Desa Pulau Tagor Dusun III, Kec. Serba Jadi, Kab. Serdang Bedagai, Provinsi Sumatera Utara. Pada tanggal 19 mei 2021 sampai dengan selesai. Penelitian ini target memakai metode purposive sampling. Memiliki perbedaan dengan cara-cara menentukan sampel yang lain, dalam penentuan sumber informasi memakai cara purposive terlebih dahulu dilandasi tujuan ataupun pertimbangan tertentu. Oleh sebab itu, saat pengambilan sumber informasi harus 
berdasarkan pada maksud yang sudah ditentukan sebelumnya, purposive bisa juga diartikan sebagai maksud dari tujuan atau kegunaan [6].

Subjek dalam melakukan penelitian yakni seluruh murid kelas VIIIA MTsPN Desa Pulau Tagor Kecamatan Serba Jadi, dengan jumlah 23 murid, dan 3 murid dipilih sebagai subjek wawancara, murid VIII A dipilih karena sudah mempelajari sistem persamaan linear dua variabel di semester ganjil.

Prosedur penelitiam Membuat soal dengan jumlah 4 soal, kemudian soal diberikan pada murid sesudah dilaksanakan validasi instrumen soal dan dinyatakan layak dipakai oleh validator ahli di bidang matematika. Melakukan pemeriksaan pada lembar jawaban murid. dipilih beberapa murid supaya dapat melakukan wawancara. Mewawancarai para murid ini bertujuan supaya dapat menegaskan hasil murid terhadap ujian.

Kemudian hasil dari wawancara serta ujian tertulis yang sudah dilaksanakan dideskripsikan peneliti. selanjutnya dilaksanakan triangulasi terhadap informasi yakni membandingkan kedua informasi dari aktivitas yang didapat supaya dapat mendapatkan informasi valid yang akan dideskripsikan. Informasi yang sudah didapat akan dideskripsikan dan diuraikan terakhir akan dianalisis.

Analisis informasi mencakup tiga aktivitas yang sudah dilaksanakan secara bersamaan yakni dengan reduksi informasi diantaranya; penyajian informasi, verifikasi (pengecekan) informasi serta penarikan simpulan. Instrumen yang dipakai supaya dapat menghimpun informasi yakni tes tertulis dan wawancara, ujian tertulis yang akan peneliti gunakan berbentuk uraian dan bersifat diagnostic. Instrumen ujian tertulis dipakai sesudah diperiksa oleh validator serta dinyatakan sudah memenuhi validitas isi. Wawancara penelitian memakai wawancara yang tidak terstruktur. Pengumpulan informasi memakai cara tes tertulis, wawancara, dokumentasi dan tringulasi. dalam penilitian ini dipakai triangulasi informasi menerapkan metode, yang sesuai dengan Tringulasi dilaksanakan bertujuan supaya dapat pengecekan terhadap pemakaian metode pengumpulan informasi, berkenaan mengnai apakah informasi yang diperoleh dengan metode secara interviuw sama dengan dipakainya metode observasi, atau jawaban dari observasi apakah sesuai dengan informasi yang didapat pada saat interview [7].

Penelitian ini dilaksanakan triangulasi informasi dengan cara membandingkan hasil jawaban murid-siswi yang melakukan ujian dan dengan adanya persepsi melalui wawancara. Teknik Analisis menerapkan analisis informasi secara kualitatif. Informasi kualitatif yangakan dianalisis dipakaiteknik analisis secara deskriptif induktif.

Analisis deskriptif, induktif merupakan proses pemikiran yang bertujuan supaya dapat mengambil pengertian dan kesimpulan yang bersifat umum, dengan berdasarkan informasi atau fakta yang konkret dan bersifat khusus [8]. Informasi yang sudah terkumpul tersebut kemudian dianalisis memakai cara model interaktif yang dipakai oleh Miles dan Huberman Mereduksi informasi, penyajian, dan penarikan kesimpulan dari informasiinformasi yang sudah dikumpulkan [9].

\section{HASIL DAN PEMBAHASAN}

Temuan Khusus melalui Penelitian yang dilaksanakan dengan Ujian Tertulis mengenai sistem persamaan linear 2 variabel di MTSPN Desa Pulau Tagor. Berikut ini kekeliruan yang ditemukan 
pada lembar jawaban murid dideskripsikan sebagai berikut:

\section{Kesalahan pada soal nomor 1}

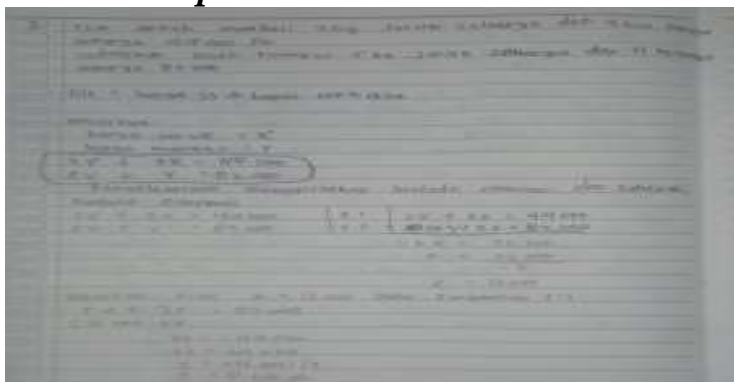

\section{Gambar 1. Contoh Jawaban S2 Keliru Mengartikan Soal ke dalam Model Matematika}

Berdasarkan dari gambar diatas hasil analisis didapatkan bahwa variabel yang dipakai oleh siswa supaya dapat membuat model matematika tidak sesuai dengan variabel yang sudah ditentukan, supaya dapat menjadi pemisalan harga jeruk dan harga mangga yang sudah diketahui dalam soal.

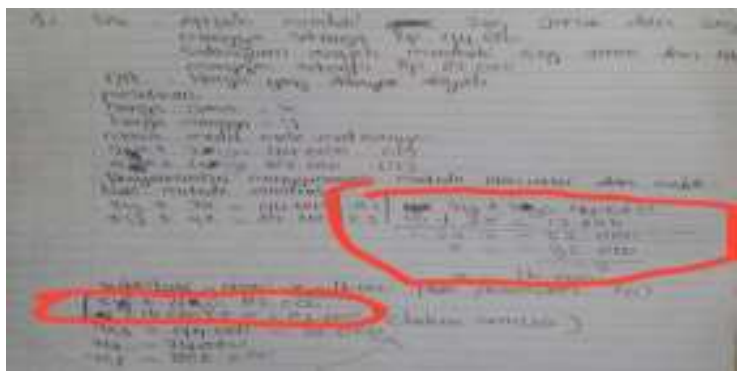

Gambar 2. Contoh Jawaban S11 Keliru Tentang Metode Eliminasi dan Substitusi

Berdasarkan Gambar 3 didapatkan murid tidak menentukan KPK dari bilangan yang ingin dikalikan guna supaya dapat menyamakan koefisien dahulu dikeliru satu variabel, akibatnya tidak dapat membuang keliru satu variabel yang seharusnya hal itu dilaksanakan, sehingga nilai dari variabel yang lain tidak dapat ditemukan. murid tidak menuliskan koefisien dan variabel y dengan tepat pada metode substitusi, ketika mensubtitusi nilai $\mathrm{x}$ ke persamaan (II).

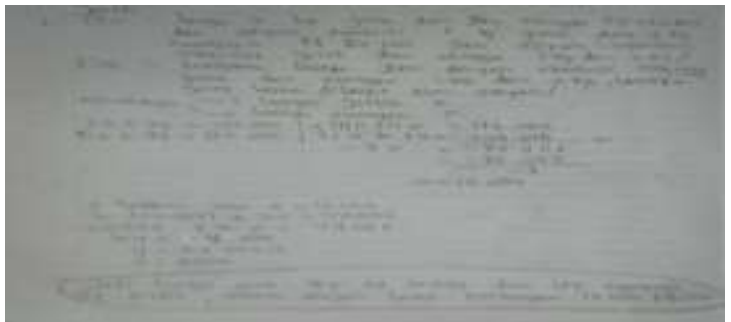

Gambar 3. Contoh Jawaban S14

Kekeliruan dalam Menarik Kesimpulan Saat Menentukan Jawaban Akhir

Gambar 4 ditemukan bahwa dalam menentukan jawaban akhir masih ada murid yang tidak mengkoordinir apa yang ditanyakan dalam soal. sehingga penarikan kesimpulan pada penyelesaian permakeliruan soal nomor satu terdapat kekeliruan.

\section{Gambar 4. Contoh Jawaban S3 Keliru pada Operasi Bilangan}

Gambar 5 dijumpai informasi ada beberapa murid dalam mengurangkan bilangan tidak tepat karena tidak dapat memakai syarat operasi perhitungan secara akurat. Sehingga hasil pengurangan pada bilangan tersebut tidak benar.

\section{Kesalahan murid dalam soal nomor 2}

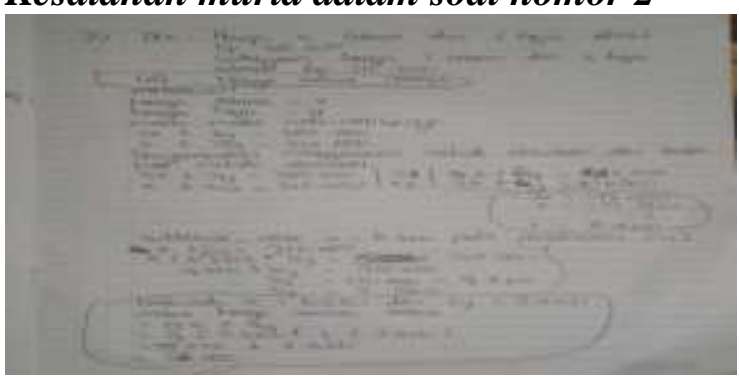

Gambar 5. Contoh Jawaban Murid S7 Keliru Konsep, Prinsip dan Operasi 
Berdasarkan analisis informasi yang sudah dilaksanakan, pada Gambar 7 bahwa murid keliru dalam pengertian makna petanyaan soal, karena dalam menuliskan apa yang ditanyakan di dalam soal pertanyaan dengan penyelesaiannya tidak sesuai, keliru dalam mengurangkan operasi bentuk aljabar pada metode eliminasi, dan dalam menarik kesimpulan pada jawaban akhir, tidak mengkoordinir apa yang ditanyakan pada soal nomor 2 .

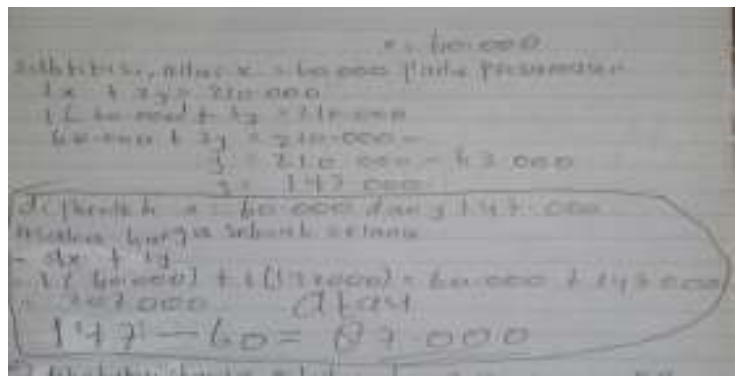

\section{Gambar 6. Contoh Jawaban Murid S19 Kekeliruan pada Prinsip}

Analisis informasi yang sudah dilaksanakan, didapat informasi bahwa murid Keliru dalam menentukan jawaban akhir, dan kelirumenarik kesimpulan karena tidak sesuai dengan apa yang ditanyakan dalam soal nomor 2 .

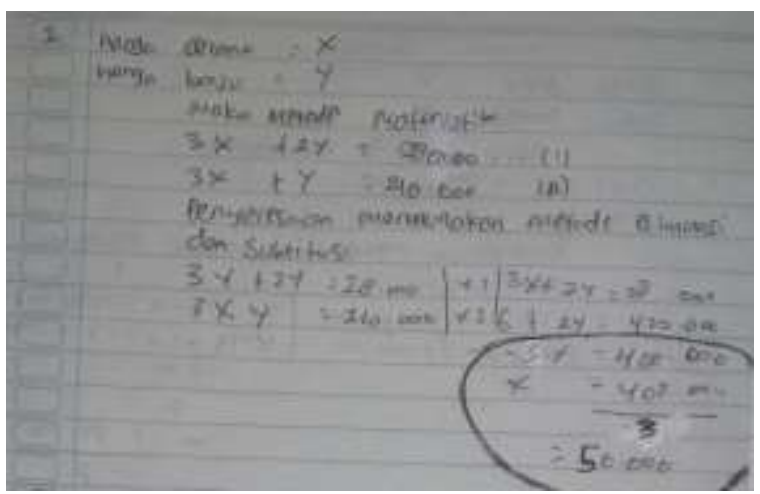

\section{Gambar 7. Contoh Jawaban Murid S10 Keliru Operasi}

Sesudah analisis yang dilaksanakan, pada gambar sembilan didapat bahwa murid keliru dalam membagikan bilangan bulat, pada metodeeliminasi, karena mendapatkan hasil yang tidak tepat.

\section{Kesalahan murid dalam soal nomor 3}

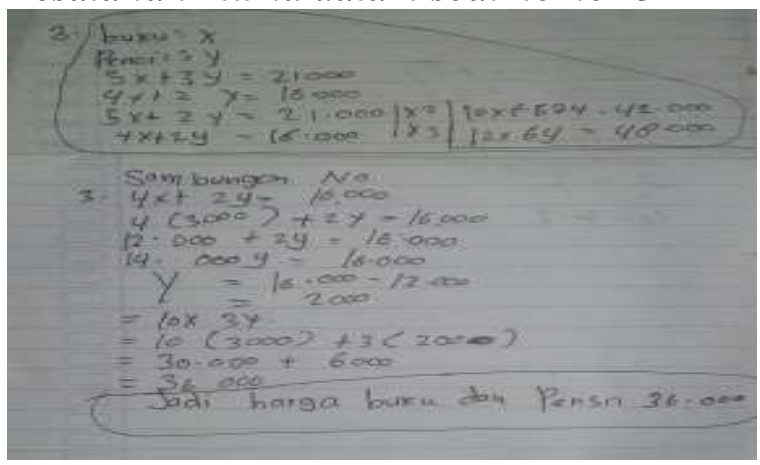

Gambar 8. Contoh Jawaban Murid S23 Keliru Konsep, Prinsip dan Operasi

Analisis informasi yang sudah dilaksanakan, bahwa murid keliru dalam pengertian soal, karena murid tidak bisa menuliskan kembali yang diketahui dan ditanya pada soal nomor 3. Murid S23 juga mengalami kekeliruan dalam mengurangkan bilangan bulat pada metode substitusi, kesimpulan pada jawaban akhir tidak mengkoordinir perihal yang ditanyakan pada soal nomor tiga.

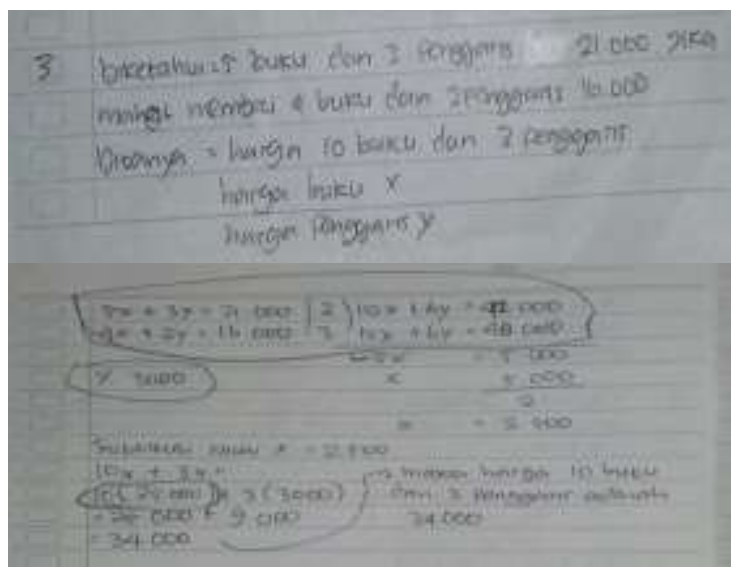

\section{Gambar 9. Contoh Jawaban Murid S6 Keliru Konsep dan Operasi}

Sesudah dilaksanakan analisis,, didapatkan informasi bahwa murid dalam memakai metode eliminasi karena simbol perkalian pada metode eliminasi tidak dituliskan, keliru dalam operasi bilangan bulat, dapat dilihat pada gambar diatas, hasil operasinya tidak tepat, dan murid S20 keliru dalam memasukkan nilai $\mathrm{x}$ pada penyelesaian memakai metode substitusi. 


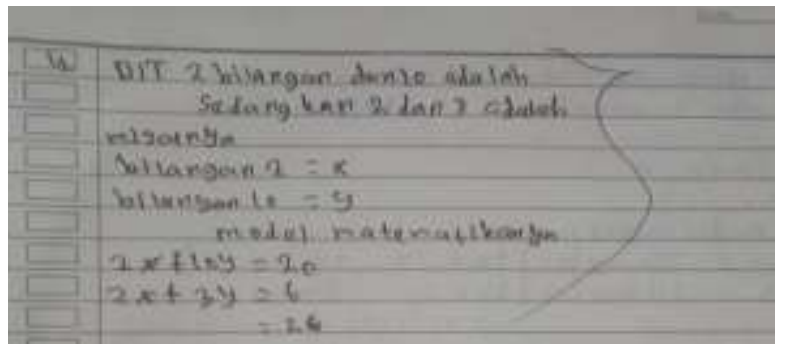

Gambar 11. Contoh Jawaban Murid S17 Keliru dalam Pengertian Soal

Pada gambar di atas, didapat informasi bahwa murid keliru menuliskan kembali apa yang sudah ditanyakan dalam soal, keliru dalam membuat model matematika pada penyelesaian soal, dan tidak menyantumkan yang diketahui dari pertanyaan.

\section{Gambar 11. Contoh Jawaban Murid S4 Keliru dalam Membuat Model Matematika}

Analisis informasi melalui melalui jawaban siswa yang dapat dilihat pada gambar 14 diketahui ternyata ada murid membuat model matematika yang tidak sepaham dengan apa yang diketahui dalam soal nomor empat.

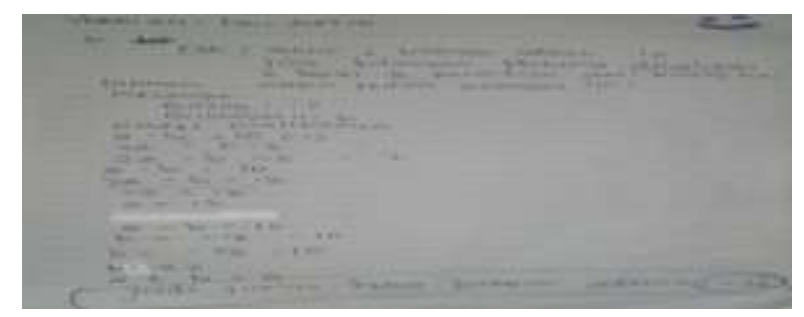

\section{Gambar 12. Contoh Jawaban Murid S21 Keliru dalam Menentukan Jawaban Akhir}

Gambar 15. terlihat bahwa murid menentukan jawaban akhir pada soal nomor 4, ditemukan hasil akhir yang dijawab dengan cara tanpa menuliskan penyelesaian yang ditanyakan pada soal.

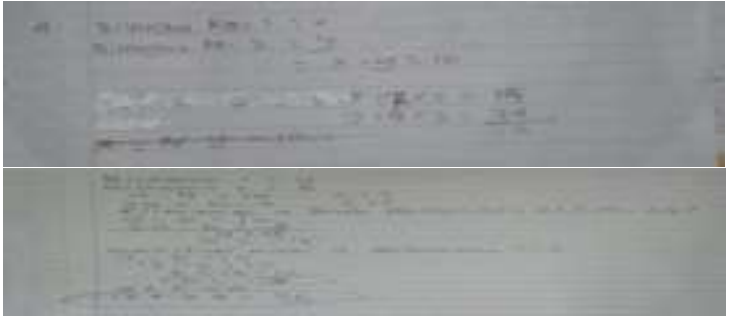

\section{Gambar 13. Contoh Jawaban Murid} S13 Kekeliruan Operasi

Analisis informasi yang sudah dilaksanakan, bahwa murid keliru dalam menjumlahkan bilangan bulat. Kesalahan murid dihitung dengan memakai rumus berikut :

Keterangan:

$$
P i \frac{x i}{\sum x} 100 \%
$$

Pi: Persemntase dari kekeliruan murid pada jenis ke-I $(\%)$

Xi: Jumlah kekeliruan pada setiap jenis kekeliruan \%

$\sum \mathrm{x}$ : Jumlah seluruh murid

Tabel 1. Rekapitulasi Keseluruhan Nilai Murid Berdasarkan Predikatnya.

\begin{tabular}{ccc}
\hline Predikat & Rentang Nilai & Jumlah murid \\
\hline A & $93-100$ & 3 \\
B & $84-92$ & 4 \\
C & $75-83$ & 8 \\
D & $<75$ & 8 \\
\hline
\end{tabular}

Sesudah dilaksanakan berbagai analissi informasi, didapatkan berbagai kekeliruan murid dalam mengerjakan soal mengenai sistem dari persamaan linear 2 variabel, dan faktor yang menyebabkanny digolongkan berdasarkan predikat yang didapat.

Siswa yang mendapatkan predikat B. kekeliruan yang dilaksanakan oleh murid di antaranya adalah kesalahan pada konsep matematika yang menyebabkannya karena murid tidak paham tentang konsep sistem persamaan linear dua variabel, dan hanya fokus pada contoh soal yang pernah diberikan. Kosep menjadi sangat penting dalam pembelajaran matematkika sehingga 
diperlukan pemahaman yang baik terhadap konsep matemaika. Tujuannya adalah agar siswa tidak melakukan kesalahan konsep secara berkelanjutan. Seperti yang kita ketahui bahwa konsep adalah pondasi dasar dalam matematika [10]. Perlu adanya kemampuan guru untuk memberikan pembelajaran yang menanamkan konsep matematika kepada siswa sehingga siswa dapat melakukan pengerjaan soal matematika dengan baik dan benar.

Siswa yang mendapatkan predikat C. sesudah dianalisa yang menyebabkan dari murid mendapatkan $\mathrm{C}$ adalah salah dan operasi dikarenakan para murid tidak menguasai pembelajaran mengenai bentukbentuk aljabar. Pentingnya penguasaan operasi bentuk aljabar menjadikan pondasi dalam operasi hitung matematika khususnya pada materi persamaan linier dua variable. Siswa-siswa yang mempunyai kemampuan matematika sedang atau rendah, cara yang digunakan untuk memecahkan soal, cenderung memberikan jawaban yang panjang lebar dan terkadang kurang akurat, bahkan banyak siswa yang kemampuan matematikanya rendah mengalami kesulitan untuk menemukan cara dalam memecahkan masalah matematika [11].

Siswa yang mendapatkan predikat D, kekeliruan yang dilaksanakan oleh murid tersebut sesudah dianalisis ditemukan aalah kesalahn pada Konsep disebabkan karena hal ini menjadi kebiasaan murid dan murid merasa lambat dalam berhitung dan merasa takut jawaban tidak selesai terjawab semua. Serta kesalahan prinsip yang menyebabkannya karena kurang teliti membaca dan mengerjakan soal.

Solusi pemecahan masalah empat langkah penyelesaian, yaitu memahami masalah, menyelesaikan masalah, merencanakan penyelesaian, dan melakukan pengecekan kembali terhadap semua langkah yang telah dikerjakan [12]. Langkah pembelajaran untuk meminamlisi kesalahan dan kesulitan siswa dalam materi persamaan linier dua variabel ini dapat digunakan untuk perbaikan proses keiatan pembelajaran.

Mengetahui bentuk kesalahan siswa berdasarkan kategori tersebut, nantinya guru dapat mengantisipasi agar tidak terjadi kesalahan serupa di masa mendatang serta bisa menangani secara cepat dan tepat bila kesalahan [13]. Harapannya dengan mengetahui dan melakukan analisis kesalahan ini menjadi bahan pertimbnagan bagi guru untuk melakukan perbaikan proses pembelajaran. Kegiatan pembelajaran dapat lebih efektif dan efisien guna meminamilsir karena sudah menganalisis kesulitan siswa dalam mempelajari materi persamaan linier dua variabel. Hal ini juga senada dengen penelitian sebelumnya yang menyatakan bahwa tujuan analisis kesalahan adalah melakukan evaluasi pembelajaran sehingga bisa memilih suatu metode yang tepat dan bervariasi dalam proses pembelajaran untuk mencari solusi alternatif sehingga kesalahan tersebut tidak berkelanjutan dan tujuan pembelajaran dapat tercapai maksimal [14].

\section{SIMPULAN}

Hasil analisis ditemukan bahwa Jumlah kekeliruan murid pada kekeliruan konsep sebanyak 22 dengan persentase sebanyak $95,65 \%$, kekeliruan pedoman dan operasi sebanyak 20 dengan persentase sebanyak 86, $95 \%$. Nilai akhir $=\frac{\text { skoryangdiperoleh }}{\text { skortotal }} \times$ 100. Berikut ini disajikan jumlah keseluruhan murid berdasarkan predikatnya, dengan KKM 75 pada muridsiswi kelas 8 A MTsPN Desa Pulau Tagor. faktor yang menyebabkan para murid melakukan kekeliruan saat mengerjakan permakeliruan dalam sistem persamaan linear 2 variabel yakni: Kurangnya pemahaman tentang konsep .materi yang 
sudah dipelajari, Murid hanya fokus pada contoh soal, kurang menguasai dalam pengoperasian sistem aljabar, tidak teliti dalam menjawab pertanyaan yang diberikan.

\section{DAFTAR PUSTAKA}

[1] D. Siregar, "Analisis Kekeliruan Murid dalam Mengerjakan Soal Cerita Matematika Berdasarkan Prosedur Newman di SMP Muhammadiyah 02 Medan," Universitas Sumatera Utara, 2018.

[2] C. CA and Sutriyono, "Analisis Kekeliruan Murid dalam Mengerjakan Soal pada Materi Operasi Penjumlahan dan Pengurangan Bentuk Aljabar Bagi Murid Kelas VII SMP Kristen 2 Salatiga," JTAM (Jurnal Teor. dan Apl. Mat., vol. 2, no. 1, pp. 26-30, 2018.

[3] A. Yulianingsih, "Analisis Kekeliruan Konsep Pecahan pada Semua Kelas VIII A SMP Negeri 13 Satu Atap Tanjung Pinang. Mosharafa: Jurnal Pendidikan Matematika," J. Pendidian Mat., vol. 7, no. 2, p. 199, 2018.

[4] A. Wijaya and Masriyah, "Analisis Kekeliruan Murid dalam Mengerjakan Soal Cerita Materi Sistem Persamaan Linear Dua Variabel," J. MathEdunusa, vol. 2, no. 1, pp. 10-16, 2013.

[5] R. Juwita, Analisis Kekeliruan dalam Mengerjakan Soal Sistem Persamaan Linear Dua Variabel. Skripsi Tarbiyyah dan Keguruan Pendidikan Matematika. Makasar: UIN Alauddin Makasar, 2015.

[6] A. Yusuf, Metode Penelitian: Kuantitatif, Kualitatif, dan Penelitian Gabungan. Jakarta: Kencana, 2014.

[7] B. B, Penelitian Kualitatif: Komunikasi, Ekonomi, Kebijakan Publik, dan Ilmu Sosial Lainnya. Jakarta: Kencana, 201AD.
[8] N. Marpaung, "Analisis Kekeliruan Murid dalam Mengerjakan Soal Matematika di MTs. Swasta Aisyiah Sumatera Utara.," UIN Sumatera Utara, 2018.

[9] Sugiyono, Metode Penelitian Kuantitatif, Kualitatif dan $R \& D$,. Bandung: Alfabeta, 2011.

[10] T. Andriani, I. K. Suastika, and N. R. Sesanti, "Analisis Kesalahan Konsep Matematika Siswa dalam Menyelesaikan Soal Trigonometri Kelas X TKJ SMKN 1 Gempol Tahun Pelajaran 2016/2017," $P i$ Math. Educ. J., vol. 1, no. 1, pp. 3439, 1970, doi: 10.21067/pmej.v1i1.1998.

[11] D. Rosdian, "Pengembangan Perangkat Pembelajaran Matematika Model Role Playing Bernuansa Pendidikan Karakter pada Kemampuan Komunikasi Matematis Siswa," in Seminar Nasional Matematika dan Pendidikan Matematika (SNMPM) Universitas Swadaya Gunung Jati Cirebon, 2016, pp. 440-460.

[12] Eviliyanida, "Pemecahan Masalah Matematika," Visipena, vol. 1, no. 2, pp. 10-17, 2010.

[13] S. D. Aini, U. R. Jannah, and R. Masruroh, "Identifikasi Kesalahan Siswa dalam Menyelesaikan Masalah Trigonometri," J. SIGMA, vol. 3, no. 1, pp. 17-25, 2017.

[14] M. Farhan and I. Zulkarnain, "Analisis Kesalahan Mahasiswa pada Mata Kuliah Kalkulus Peubah Banyak Berdasarkan Newmann' s Error Analysis," J. Kaji. Pendidik. Mat., vol. 4, no. 2, pp. 121-134, 2019. 